Research article

\title{
Morphology of two Mastogloia species (Bacillariophyta) from Lac de Guiers (Senegal) and comparison with the type material of $M$. braunii
}

\author{
Bart VAN DE VIJVER ${ }^{1,2, *}$, Cheikh Abdoul Kader FOFANA ${ }^{3}$, El Hadji SOW ${ }^{4}$, \\ Christine COCQUYT ${ }^{5}$, Saúl BLANCO ${ }^{6} \&$ Luc ECTOR $^{7}$ \\ ${ }^{1,5}$ Botanic Garden Meise, Nieuwelaan 38, B-1860 Meise, Belgium. \\ ${ }^{2}$ University of Antwerp, Department of Biology, ECOBE, \\ Universiteitsplein 1, B-2610 Wilrijk, Belgium. \\ ${ }^{3,4}$ Université Cheikh Anta Diop, Département de Géologie, \\ Faculté des Sciences et Techniques, Dakar, Senegal. \\ ${ }^{6}$ Institute of the Environment, La Serna, 58-24007 León, Spain. \\ ${ }^{7}$ Luxembourg Institute of Science and Technology, Department of Environmental \\ Research and Innovation, rue du Brill 41, L-4422 Belvaux, Luxembourg. \\ *Corresponding author: bart.vandevijver@plantentuinmeise.be \\ ${ }^{3}$ Email: cheikh.fofana@ucad.edu.sn \\ ${ }^{4}$ Email: elhadji.sow@ucad.edu.sn \\ ${ }^{5}$ Email: christine.cocquyt@plantentuinmeise.be \\ ${ }^{6}$ Email: saul.lanza@unileon.es \\ ${ }^{7}$ Email: 1uc.ector@list.lu
}

\begin{abstract}
Two Mastogloia Thwaites ex W.Sm. taxa were found during a survey of the diatom flora of Lac de Guiers, Senegal. Based on all currently available literature, one taxon could be identified as M. belaensis M.Voigt, a species formerly described from Pakistan. The second species showed some resemblance to $M$. braunii Grunow. Analysis of the type of $M$. braunii revealed, however, important morphologic differences, leading to the description of a new species from the Senegal population: M. senegalensis Van de Vijver, Fofana, Sow \& Ector sp. nov. The present paper describes this new species and discusses and illustrates the morphology of M. belaensis and the type of M. braunii. All taxa are discussed with morphologically similar taxa.
\end{abstract}

Keywords. Bacillariophyceae, Mastogloia belaensis, Mastogloia braunii, new species, Senegal, ultrastructure.

Van de Vijver B., Fofana C.A.K., Sow E.H., Cocquyt C., Blanco S. \& Ector L. Morphology of two Mastogloia species (Bacillariophyta) from Lac de Guiers (Senegal) and comparison with the type material of M. braunii. European Journal of Taxonomy 374: 1-23. https://doi.org/10.5852/ejt.2017.374 


\section{Introduction}

In general, the aquatic freshwater diatom flora from sub-Saharan western Africa is rather poorly known. Major taxonomic and morphologic contributions were published by Zanon (1941) (French West Africa), Pinto (1948) (Guinea-Bissau), Woodhead \& Tweed (1958) (Sierra Leone), Guermeur (1954) (Senegal), Foged (1966, 1986) (Ghana and Gambia, respectively), Carter \& Denny (1982, 1987, 1992) (Sierra Leone), Compère (1991) (Senegal), Ouattara et al. (2000) (Ivory Coast), Alfinito \& Lange-Bertalot (2003) (Sierra Leone), and Compère \& Riaux-Gobin (2009) (Guinea).

During a biomonitoring project using diatoms as bio-indicators in the Senegal River, a small sampling campaign was made in 2007 on the Lac de Guiers, situated in northern Senegal, south of the city of Richard-Toll. During the analysis of the collected samples, two distinct Mastogloia Thwaites ex W.Sm. taxa have been found, presumably belonging to ' $M$. sect. Sulcatae'. The raphid genus Mastogloia is rather large and comprises at present more than 400 taxa, mostly observed in marine or brackish conditions (e.g., Novarino 1989; Pennesi et al. 2011; Lobban \& Pennesi 2014). Most Mastogloia species have naviculoid, isopolar valves (Round et al. 1990). The most typical feature of this genus is the presence of a partectal ring representing a chamber-like modification of the valvocopula, running along the inner side of the girdle. Detailed information regarding the general morphology of the genus Mastogloia can be found in Paddock \& Kemp (1990), Round et al. (1990), Pennesi et al. (2011, 2012), Lobban \& Pennesi (2014) and Al-Handal et al. (2015). The description of most species, however, has only been based on LM observations. Morphological investigations of Mastogloia species based on SEM observations are scarce and only recently increased attention is given to the ultrastructure of the different species resulting in the description of a relatively large number of new taxa (Pennesi et al. 2011, 2012, 2013; Graeff et al. 2013; Lee et al. 2014; Lobban \& Pennesi 2014; Al-Handal et al. 2015, 2016; Pavlov et al. 2016).

The objective of the present paper is to illustrate and discuss the morphology of the two Mastogloia taxa observed in the Lac de Guiers, using light and scanning electron microscopy observations and to compare them with the type material of comparable taxa such as M. braunii Grunow and M. belaensis M.Voigt and with illustrated records of similar (mostly recently described) species to reveal their identity. The type material of M. braunii was found in the Grunow collection in Vienna but, unfortunately, the search for the type of $M$. belaensis proved to be unsuccessful.

\section{Material and methods}

The Lac de Guiers is a large lake $\left(300 \mathrm{~km}^{2}\right)$ situated in the northern part of Senegal, south of the Senegal River, not far from the city of Richard Toll. The lake, with a length of $50 \mathrm{~km}$ and a maximal width of $7 \mathrm{~km}$, is the main freshwater source for the Senegalese capital Dakar, located several hundreds of $\mathrm{km}$ to the southwest. The water from the lake is likewise used for the irrigation of rice and sugar cane cultures bordering mainly the northern shores. The lake, which bottom is at almost $2 \mathrm{~m}$ below sea level, is quite shallow with an average depth of $2 \mathrm{~m}$, and a maximum depth of $4 \mathrm{~m}$ during periods of complete filling. Water level drops to less than $1.5 \mathrm{~m}$ during the dry season. The Ferlo River supplies the lake with freshwater in the south; in the north, the narrow Taoué canal connects the Senegal River with the lake filling the lake during periods of high water level. The canal replaces the former Taoué River which is dammed now to prevent the inflow of salt water from the Senegal delta into the lake (Dia \& Reynaud 1982; Compère 1991). The lake is characterized by an alkaline $\mathrm{pH}(7.4-8.5)$ and a variable conductivity from $100 \mu \mathrm{m} / \mathrm{cm}$ in the north to $1000 \mu \mathrm{S} / \mathrm{cm}$ in the south, while at the end of the dry season values of 500 $\mu \mathrm{S} / \mathrm{cm}$ in the south to $5000 \mu \mathrm{m} / \mathrm{cm}$ in the north were noted by Cogels and Gac in 1984 (Compère 1991).

Several samples were taken along the shore of Lac de Guiers. In one of the samples, SEN-42, a large population of two Mastogloia species has been found. The sample was collected from the surface 
sediment of Lac de Guiers, close to the village of Naéré, on the western side of the lake. The sampling site was characterized by a high conductivity $(3700 \mu \mathrm{S} / \mathrm{cm})$. The area was vegetated with a Typha sp. and a Phragmites sp., while in the water thick masses of Chara sp. were floating.

For the analysis of the type of Mastogloia braunii the following material was used: A. Grunow $23583-$ capsule 0645 (NMW) (raw material).

Diatom samples for LM observation were prepared following the method described in Van der Werff (1955). Subsamples of the original material were oxidized using $37 \% \mathrm{H}_{2} \mathrm{O}_{2}$ and heated to $80^{\circ} \mathrm{C}$ for approximately $1 \mathrm{~h}$. The reaction was further completed by the addition of $\mathrm{KMnO}_{4}$. Following digestion and centrifugation (three times $10 \mathrm{~min}$ at $3700 \times \mathrm{g}$ ), the material free of organic matter was diluted with distilled water for sample mounting to avoid excessive concentrations of diatom valves and frustules on the slides. A subsample from the organic-free material was mounted in Naphrax ${ }^{\circledR}$ for diatom community studies. The slides were analyzed using an Olympus BX53 microscope, equipped with Differential Interference Contrast (Nomarski), and an Olympus UC30 digital camera. Morphometric data were obtained on 50 valves of $M$. belaensis and 25 valves of $M$. senegalensis Van de Vijver, Fofana, Sow \& Ector sp. nov. Number of striae and number of partecta was measured from the middle towards the apices. Length and width of partecta were measured for the middle (largest) partecta and the most outer (smallest) partecta.

For scanning electron microscopy (SEM), part of the organic-free suspension was filtered through a polycarbonate membrane filter with a pore diameter of $5 \mu \mathrm{m}$, pieces of which were fixed on aluminum stubs after air-drying. The stubs were sputter-coated with $15 \mathrm{~nm}$ of Au and studied in a JEOL-JSM$7100 \mathrm{~F}$ at $1 \mathrm{kV}$. Micrographs were digitally manipulated and plates containing light and scanning electron microscopy images were created using Adobe Photoshop 4.0 ${ }^{\circledR}$. Diatom terminology follows Kemp \& Paddock (1989) and Paddock \& Kemp (1990). A comparison was presented with M. baldjikiana Grunow in Schmidt (1893: pl. 188, figs 1-2, Baltschik) based on observations made from slide 545 of the Types du Synopsis des diatomées de Belgique, present in the Van Heurck Collection at the Botanic Garden Meise, Belgium (BR).

\section{Results}

Class Bacillariophyceae Haeckel emend. Medlin \& Kaczmarska (Medlin \& Kaczmarska 2004)

Subclass Bacillariophycidae D.G.Mann (Round et al. 1990)

Order Mastogloiales D.G.Mann (Round et al. 1990)

Family Mastogloiaceae Mereschk. (Mereschkowsky 1903)

Genus Mastogloia Thwaites ex W.Sm. (Smith 1856)

\section{Mastogloia braunii Grunow}

Figs 1-16

Verhandlungen der Kaiserlich-Königlichen Zoologisch-Botanischen Gesellschaft in Wien 13: 156, pl. 13 fig. 2 (Grunow 1863).

\section{Type}

EGYPT: Sinaï, El-Tor, A. Grunow 23583 - capsule 0645 (NMW) (raw material).

\section{Description (type material)}

\section{Light microscopy (Figs 1-5)}


Valves elliptic-lanceolate with broadly convex margins and apiculate, cuneately protracted apices. Valve dimensions $(\mathrm{n}=5)$ : length $45-80 \mu \mathrm{m}$, width 16-21 $\mu \mathrm{m}$. Axial area narrow, lanceolate, narrowing towards the apices and the central area. Lyre-shaped hyaline (rather deep) depression present parallel to and close to the axial area, separating 1-2 rows of pseudoloculi from the striae. Central area small, transapically rectangular. Raphe lateral with undulating branches. Proximal raphe endings almost not expanded, coaxial. Distal endings hooked. Striae slightly radiate mid-valve, becoming more strongly radiate towards the apices, 15-16 in $10 \mu \mathrm{m}$. Occasionally one to several shortened striae inserted within the normal striation pattern near the central area (Fig. 2, arrows). Pseudoloculi slightly visible in LM, ca 18 in $10 \mu \mathrm{m}$. Partecta distributed along the entire partectal ring, closely attached to the margins without broad flange, reaching almost the apices. Ring composed of partecta of different size (5-6 in $10 \mu \mathrm{m}$ in the middle, $7-9$ in $10 \mu \mathrm{m}$ near the apices): the middle 6-7 partecta (length 2.4-2.6 $\mu \mathrm{m}$, width 1.6-3.1 $\mu \mathrm{m}$ ) considerable larger than the outer partecta (length 1.2-1.4 $\mu \mathrm{m}$, width 1.4-1.6 $\mu \mathrm{m}$ ).

\section{Scanning electron microscopy (Figs 6-16)}

External raphe branches clearly undulating (Fig. 6). Proximal raphe endings straight, simple to very weakly expanded (Figs 6-7). Distal raphe fissures centrally crossing the terminal nodule, elongated, weakly hooked towards the same direction, continuing onto the valve mantle (Fig. 6). Marginal crest
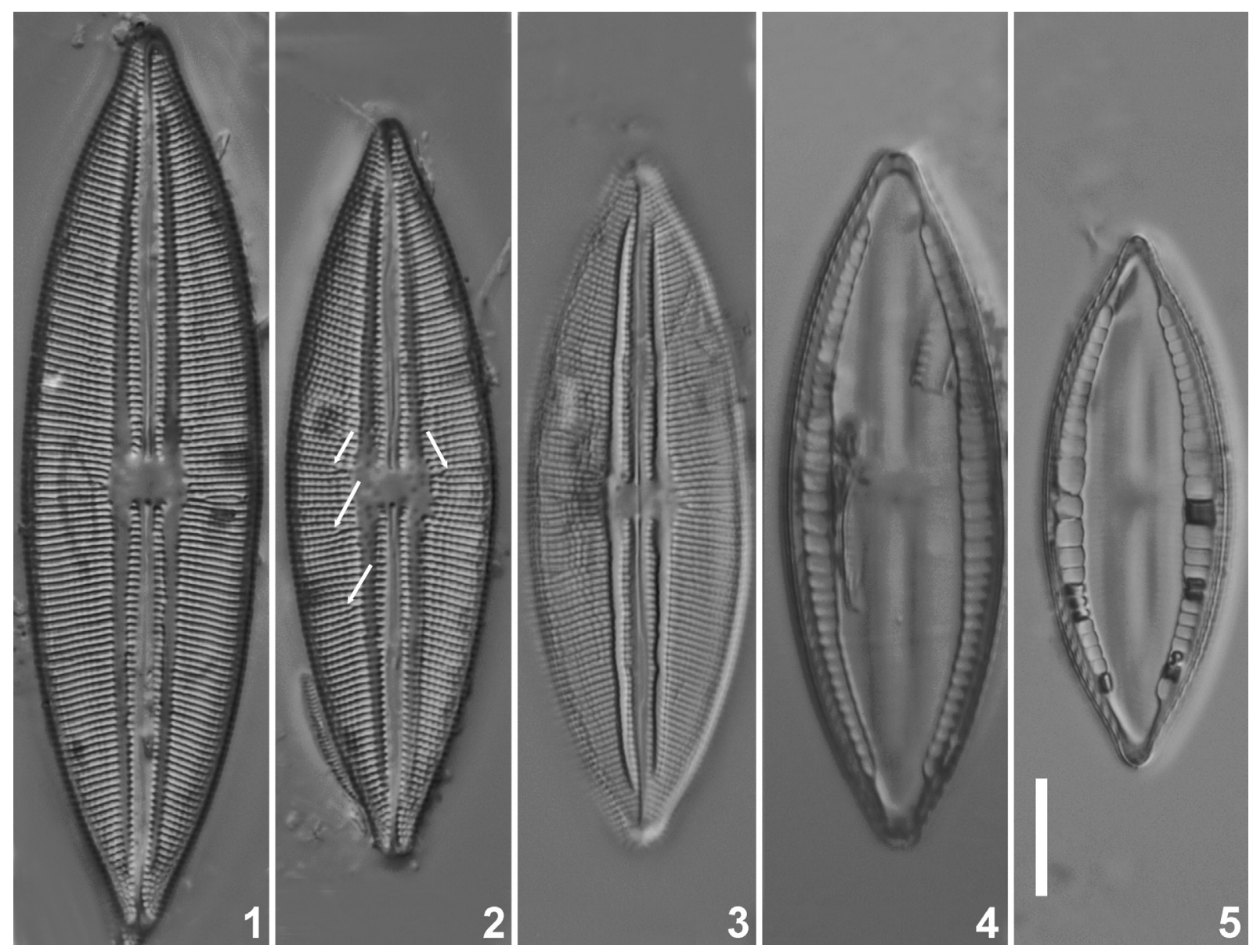

Figs 1-5. Mastogloia braunii Grunow. Light micrographs (LM) of valves from the type population (Grunow 23583 - capsule 0645, Vienna, Austria). 1-3. LM views of 3 valves showing variation in valve size and shape. The arrows in Fig. 2 indicate shortened striae near the central area. 3-4. Same valve taken at different foci. 4-5. LM views of the partectal ring with the partecta. Scale bar: $10 \mu \mathrm{m}$. 

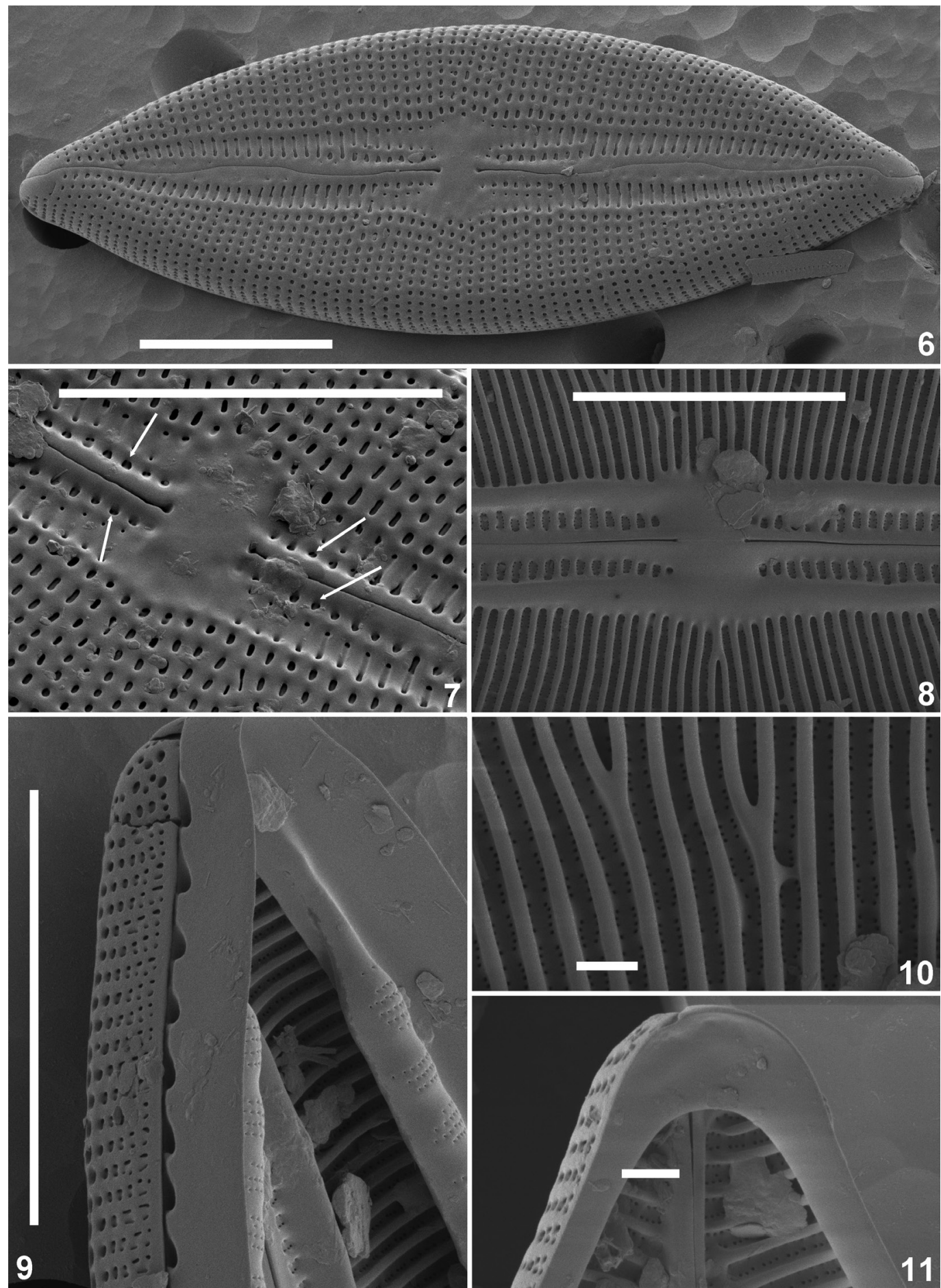

Figs 6-11. Mastogloia braunii Grunow. Scanning electron micrographs (SEM) of valves from the type population (Grunow 23583 - capsule 0645, Vienna, Austria). 6. SEM external view of an entire valve showing the shallow depressions in the axial area, the undulating external raphe branches and the terminal raphe fissures. 7. SEM external detail of the central area. The arrows indicate one row of irregularly scattered rounded pseudoloculi. 8. SEM internal detail of the central area. 9. SEM detail of the valve mantle showing the mantle striae with near the mantle edge, their typical biseriate character. 10. SEM internal view of the striae with the arrangement of the inner areolae. 11. SEM internal detail of the valve apex with the pseudoseptum. Scale bars: $6-9=10 \mu \mathrm{m} ; 10-11=1 \mu \mathrm{m}$. 

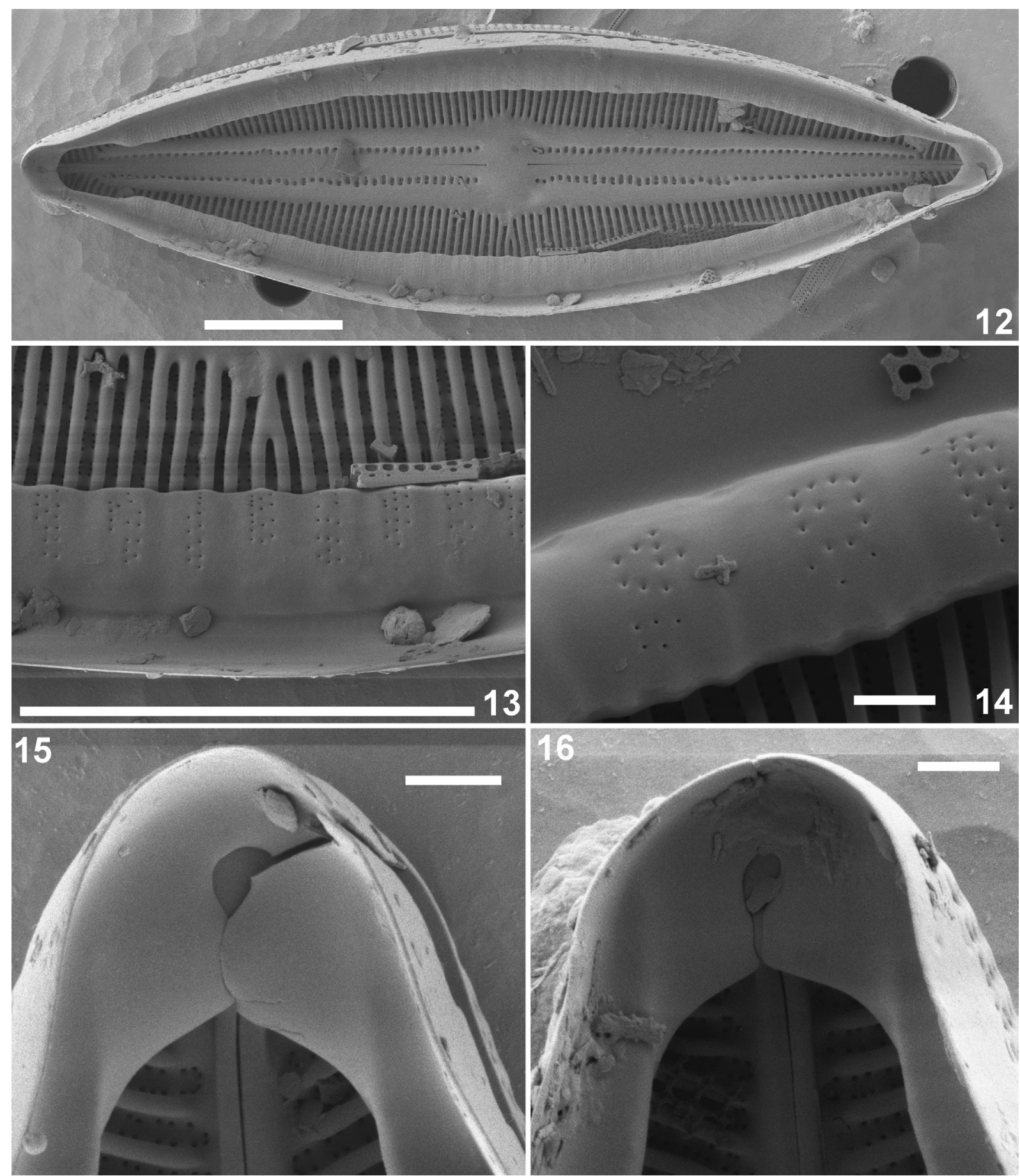

Figs 12-16. Mastogloia braunii Grunow. Scanning electron micrographs (SEM) of valves from the type population (Grunow 23583 - capsule 0645, Vienna, Austria). 12. SEM internal view of an entire valve with the partectal ring and series of partectal pores. 13. SEM internal detail of the partecta with the flange connecting the partecta with the valve margins. 14. SEM internal detail of the partecta showing the partectal walls with 2-4 series of small, rounded pores. 15-16. SEM internal details of the partectal ring near the valve apices showing the cleft with the lacunae. Scale bars: $12=1 \mu \mathrm{m} ; 13-16=10 \mu \mathrm{m}$. 
on the valve face/mantle junction absent (Fig. 6). Mantle striae uniseriate becoming biseriate near the mantle edge, composed of several rounded to irregularly shaped pseudoloculi (Fig. 9). Valve face clearly subdivided into two zones: an outer zone composed of a series of uniseriate striae, composed of a variable number of rounded pseudoloculi and a central zone restricted to both sides of the raphe-sternum, formed by a distinct lanceolate median depression (Fig. 6). Close to the raphe, one row of irregularly scattered rounded pseudoloculi present (Fig. 7, arrows), whereas in the depressions on both sides of the axial area, pseudoloculi transapically elongated, rectangular, diminishing in size towards the apices (Fig. 6). Central area flat, hyaline. Small hyaline area present at both apices (Fig. 6). Shallow depressions sometimes visible in the axial area (Fig. 6). Internally, hyaline H-shaped lyriform raphe sternum clearly raised (Fig. 8). Well-developed, raised costa-like interstriae interrupted by the raphe-sternum extending from the axial area towards the valve margins, separating the areolae (Figs 8, 10). Inner areolae arranged in groups of 6-8 per pseudoloculus (Fig. 10). Raphe branches straight with indistinct, almost straight proximal endings, terminating on a weakly raised central nodule (Fig. 8). Valve apices with pseudosepta (Fig. 11). Valvocopulae with typical partectal ring, opening near the apices through a series of partectal pores (Fig. 12). Partectal ring opening at the poles by a cleft, covering entirely the pseudosepta (Figs 12, 15-16). Lacunae clearly present (Figs 15-16). Partecta extending almost entirely to the valve apex, with only a small siliceous flange (Figs 12-13). Partecta subequal in size with the large ones grouped in the middle, the smaller ones nearer to the apices (Fig. 12). Partecta ornamented with several series of small, rounded areolae (Fig. 14).

\section{Mastogloia belaensis M.Voigt}

Figs $17-45$

Journal of the Royal Microscopical Society ser. 3 75: 189, pl. 1 fig. 1, 5, 6, 7 (Voigt 1956).

\section{Description (Senegal population)}

\section{Light microscopy (Figs 17-32)}

Valves lanceolate to elliptic-lanceolate with convex margins. Apices non-protracted, acutely rounded to slight protracted, subrostrate. Valve dimensions $(\mathrm{n}=50)$ : length 31-99 $\mu \mathrm{m}$, width 11.5-20.0 $\mu \mathrm{m}$. Axial area narrow, lanceolate, narrowing towards the apices. Lyre-shaped hyaline zone present close to the axial area, separating one row of pseudoloculi from the striae. Central area rather small, rectangular. Raphe lateral with clearly undulating branches. Proximal raphe endings indistinct, straight. Distal endings hooked towards the same direction. Striae radiate throughout, becoming less radiate and even parallel to slightly divergent (Fig. 25) towards the apices, 13-15 in $10 \mu \mathrm{m}$. Pseudoloculi quite large, well visible in LM, 15-20 in $10 \mu \mathrm{m}$. Partectal ring clearly displaced towards the middle of the valve, composed of partecta of different size (6-8 in $10 \mu \mathrm{m})$ : the middle $4-8$ partecta (length $1.9-2.9 \mu \mathrm{m}$, width $1.8-3.9 \mu \mathrm{m})$ considerable larger than the outer partecta (length $0.9-1.4 \mu \mathrm{m}$, width $1.2-1.8 \mu \mathrm{m}$ ).

\section{Scanning electron microscopy (Figs 33-45)}

External raphe branches clearly undulating (Fig. 34). Proximal raphe endings simple, very weakly expanding, slightly deflected (Figs 34-35). Distal raphe fissures centrally crossing the terminal nodule, elongated, hooked towards the same direction, continuing onto the valve mantle, terminating almost near the mantle edge (Fig. 36). Very low, slightly thickened marginal crest visible on the valve face/ mantle junction separating the striae on the valve face from the mantle areolae by a hyaline line (Fig. 34). Mantle striae entirely uniseriate, composed of several, usually transapically elongated to slit-like pseudoloculi (Figs 33-34, 36, 38). First pseudoloculi near the junction rounded (Figs 36, 38). Valve face almost flat, subdivided into two zones: outer zone composed of uniseriate striae, with up to four rounded pseudoloculi, central zone formed by one row of rounded pseudoloculi close to the axial area and one row of transapically elongated rectangular pseudoloculi (Figs 34-35). Near the central 


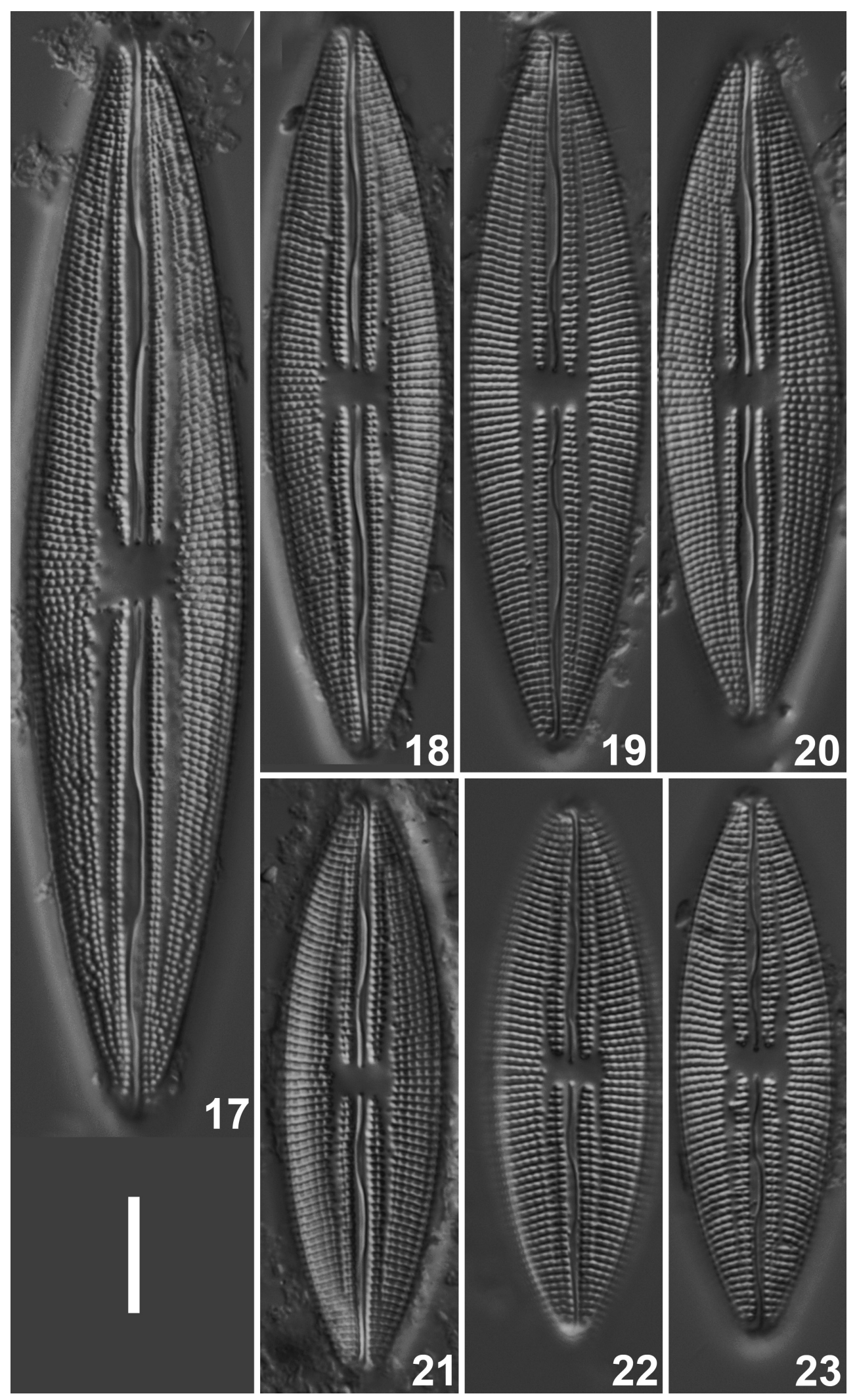

Figs 17-23. Mastogloia belaensis M.Voigt. Light micrographs (LM) of valves from the Lac de Guiers population (Van de Vijver sample $S E N-42$ ). LM views of several specimens showing variation in valve size and shape. Scale bar: $10 \mu \mathrm{m}$. 

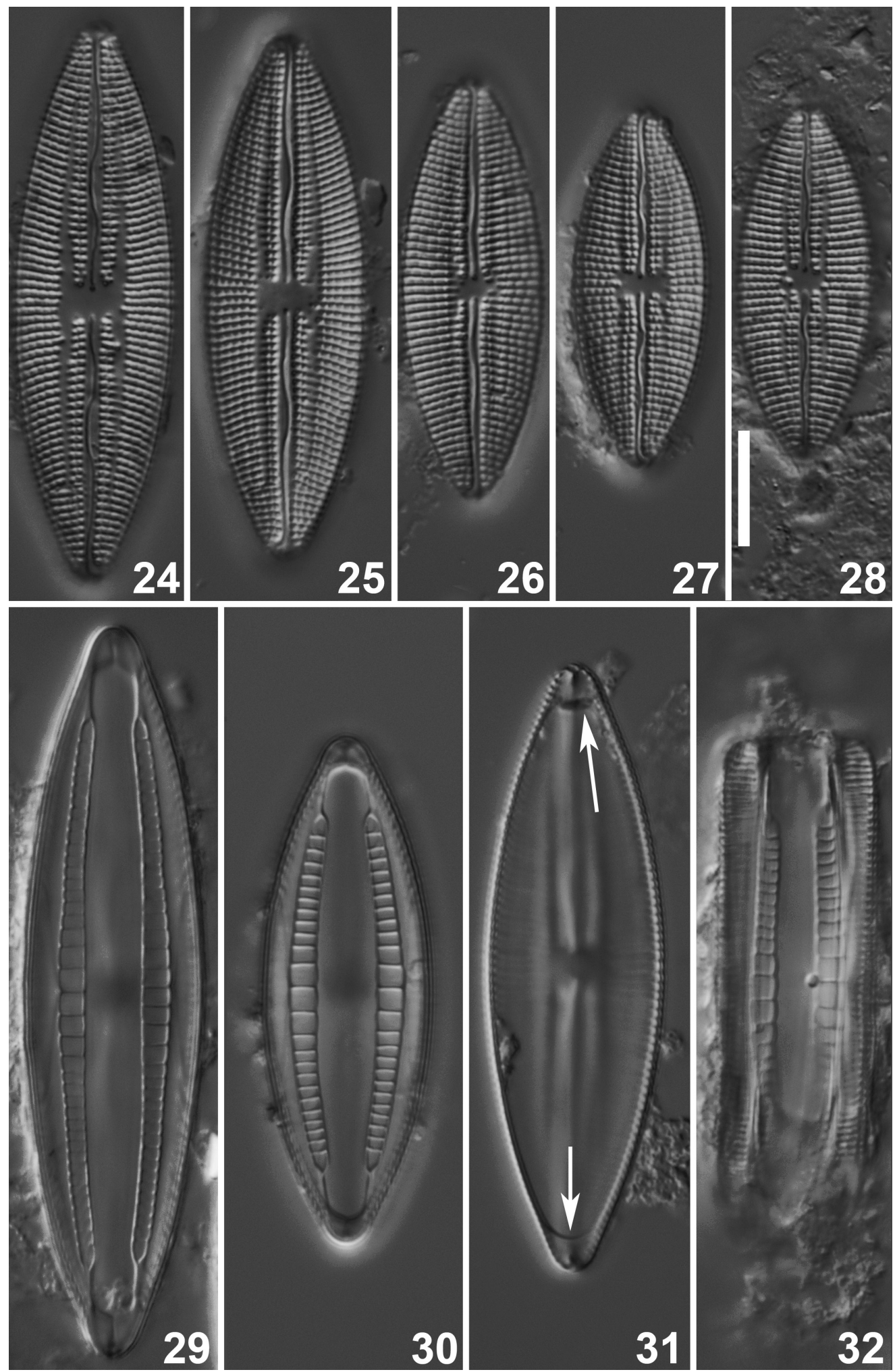

Figs 24-32. Mastogloia belaensis M.Voigt. Light micrographs (LM) of valves from the Lac de Guiers population (Van de Vijver sample $S E N-42$ ). 24-28. LM views of several smaller valves showing variation in valve size and shape. 29-30. LM views of the partectal ring with the partecta. 31. LM view of an entire valve with removed partectal ring showing the pseudosepta (arrows). 32. Entire frustule in girdle view. Scale bar: $10 \mu \mathrm{m}$. 

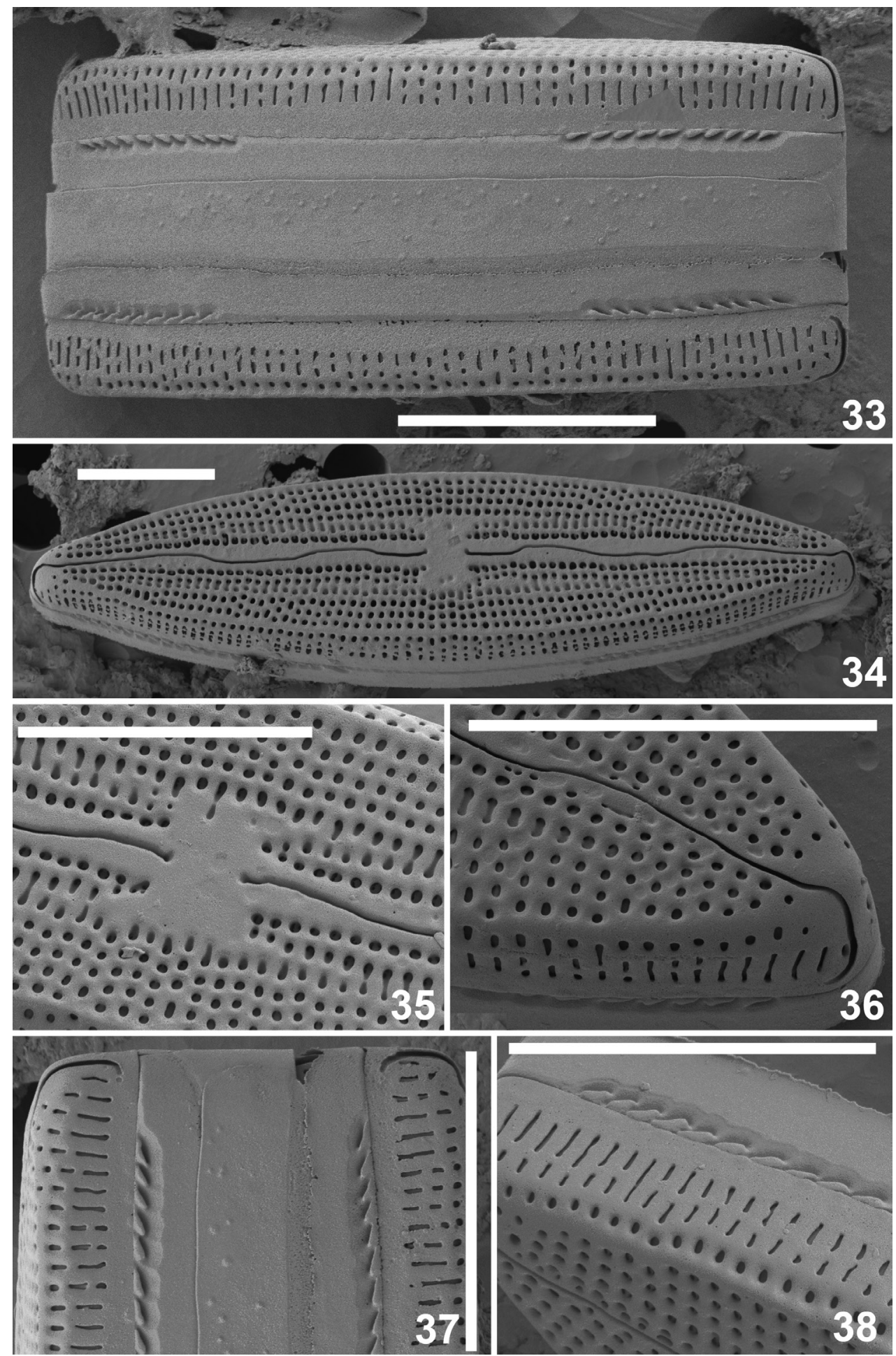

Figs 33-38. Mastogloia belaensis M.Voigt. Scanning electron micrographs (SEM) of valves from the Lac de Guiers population (Van de Vijver sample $S E N-42$ ). 33. SEM girdle view of an entire frustule showing the partectal pores and the mantle areolae. 34. SEM external view of an entire valve with typical undulating raphe branches. 35. SEM external detail of the central area. 36. SEM external detail of the valve apex. 37. SEM external detail of the apices and girdle bands of an entire frustule. 38 . SEM external detail of the valve mantle with the transapically elongated mantle areolae and the row of rounded pseudoloculi on the valve face/mantle junction. Scale bars: $10 \mu \mathrm{m}$. 

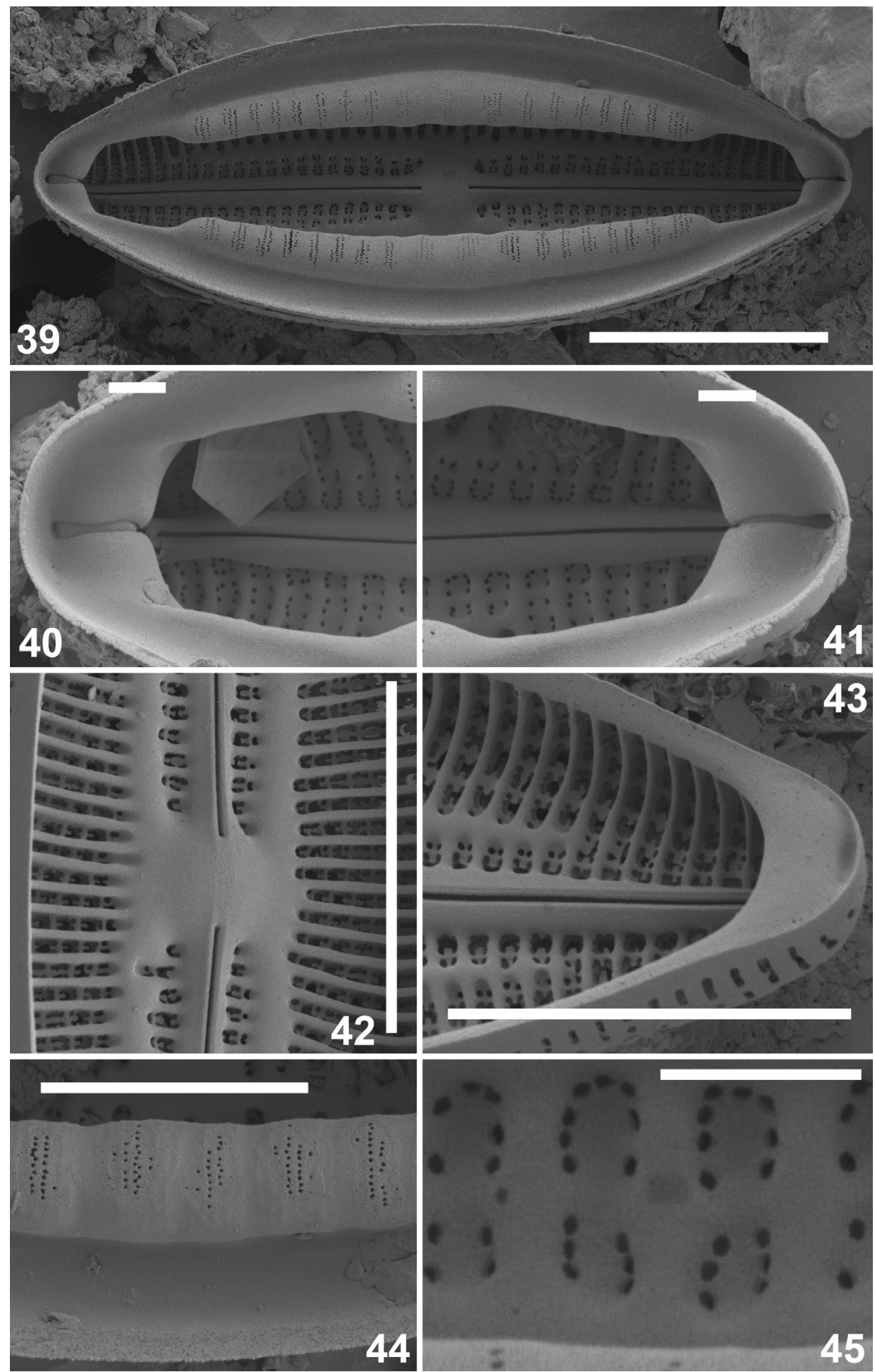

Figs 39-45. Mastogloia belaensis M.Voigt. Scanning electron micrographs (SEM) of valves from the Lac de Guiers population (Van de Vijver sample $S E N-42$ ). 39. SEM internal view of an entire valve with the typical partectal ring. 40-41. SEM internal details of the partectal ring near the valve apices showing the cleft with the lacunae. 42. SEM internal detail of the central area. 43. SEM internal detail of the valve apex with the pseudoseptum. 44. SEM internal detail of the partecta showing the partectal walls with 2-4 series of small, rounded pores. 45. SEM internal view of the inner areolae arranged in groups of 4-8 per pseudoloculus. Scale bars: $39-43=10 \mu \mathrm{m} ; 44=5 \mu \mathrm{m} ; 45=1 \mu \mathrm{m}$. 
area, rectangular pseudoloculi replaced by 1-2 small, rounded ones whereas near the apices, central transapically elongated pseudoloculi absent, outer zone with rounded pseudoloculi reaching the axial area (Fig. 36). Shallow depressions sometimes visible in the axial area (Figs 34-36). Hyaline areas present on each valve apex (Fig. 36). Internally, raphe sternum lyriform, slightly raised (Figs 39, 42). Raised thickened costa-like interstriae interrupted by the raphe-sternum extending from the axial area towards the valve margins, separating the areolae (Figs 42-43). Inner areolae arranged in groups of 4-8 per pseudoloculus (Fig. 45). Raphe branches straight with indistinct, coaxial proximal endings, terminating on a raised central nodule (Figs 39, 42). Valve apices with clear pseudosepta covering the distal raphe endings (Fig. 43).

Girdle composed of the valvocopulae and one open, non-perforated copula (Figs 33, 37). Small siliceous papillae present on the copula (Fig. 37). Valvocopulae with typical partectal ring, opening near the apices through a series of elongated partectal pores (Figs 33, 37-38). Partectal ring open, one end closed but with a cleft forming a narrow lacuna (Fig. 40), other split with a cleft (Fig. 41), covering entirely the pseudosepta. Partecta extending to almost $1 / 4$ to $1 / 6$ from the valve apex, clearly separated from the valve margin by a siliceous flange (Fig. 39). Partecta subequal in size with the large ones grouped in the middle, the smaller ones closer to the apices (Fig. 39). Partecta ornamented with several series of small, rounded areolae, loosely aggregated in very unclear plaques and arranged inwardly (Fig. 44).

Mastogloia senegalensis Van de Vijver, Fofana, Sow \& Ector sp. nov. Figs 46-65

\section{Etymology}

The new species is named after Senegal, the country from which the new species is described.

Type

SENEGAL: Lac de Guiers, 10 Mar. 2007, B. Van de Vijver sample SEN-42 (holo-: slide no. BR-4500; iso-: PLP-334; University of Antwerp, Belgium).

\section{Description}

\section{Light microscopy (Figs 46-55)}

Valves elliptic-lanceolate with broadly convex margins. Apices slightly protracted, cuneately rounded, never rostrate. Valve dimensions $(\mathrm{n}=25)$ : length $26-56 \mu \mathrm{m}$, width $11.5-17.0 \mu \mathrm{m}$. Axial area narrow, linear-lanceolate, narrowing towards the apices. Lyre-shaped hyaline depression present close to the axial area, separating 1-2 rows of pseudoloculi from the striae. Central area rather small, transapically elliptical to rectangular. Raphe lateral with undulating branches. Proximal raphe endings weakly expanded, coaxial. Distal endings hooked towards the same direction. Striae slightly radiate throughout, becoming more strongly radiate towards the apices, $16-18$ in $10 \mu \mathrm{m}$. Occasionally one to several shortened striae inserted near the central area (Figs 46, 48). Pseudoloculi well visible in LM, 15-20 in $10 \mu \mathrm{m}$. Partecta distributed along the entire partectal ring, closely attached to the margins without broad flange, reaching almost the apices. Partecta of different size $(5-7$ in $10 \mu \mathrm{m})$ : the middle $4-5$ partecta (length 1.9-3.0 $\mu \mathrm{m}$, width 1.9-3.1 $\mu \mathrm{m}$ ) considerable larger than the outer partecta (length 1.1-1.8 $\mu \mathrm{m}$, width $1.2-2.0 \mu \mathrm{m})$.

\section{Scanning electron microscopy (Figs 56-65)}

External raphe branches clearly undulating (Fig. 57). Proximal raphe endings simple to very weakly expanded, slightly deflected (Figs 57-58). Distal raphe fissures centrally crossing the terminal nodule, elongated, hooked towards the same direction, continuing onto the valve mantle (Figs 57, 58). No marginal crest on the valve face/mantle junction (Fig. 59). Mantle striae uniseriate near the valve face/ 

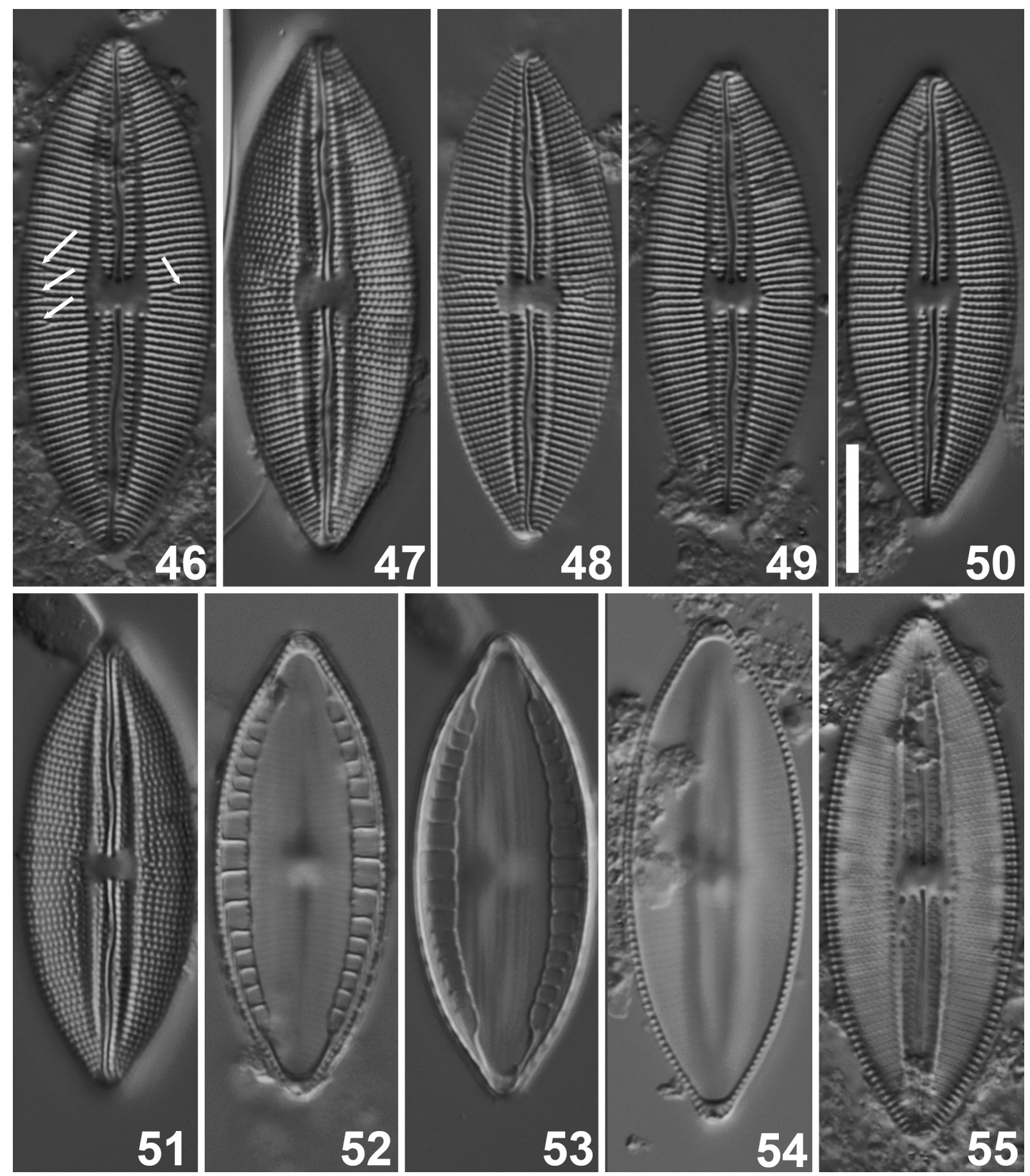

Figs 46-55. Mastogloia senegalensis Van de Vijver, Fofana, Sow \& Ector sp. nov. Light micrographs of valves from the Lac de Guiers type population (Van de Vijver sample SEN-42). 46-51. LM views of several specimens showing variation in valve size and shape (the arrows in Fig. 46 show typical bifurcating striae near the central area). 52-53. LM views of the partectal ring with the partecta. 54. LM view of an entire valve with removed partectal ring showing the pseudosepta. 55. LM view of an entire valve with removed partectal ring showing the valve interior. Scale bar: $10 \mu \mathrm{m}$. 

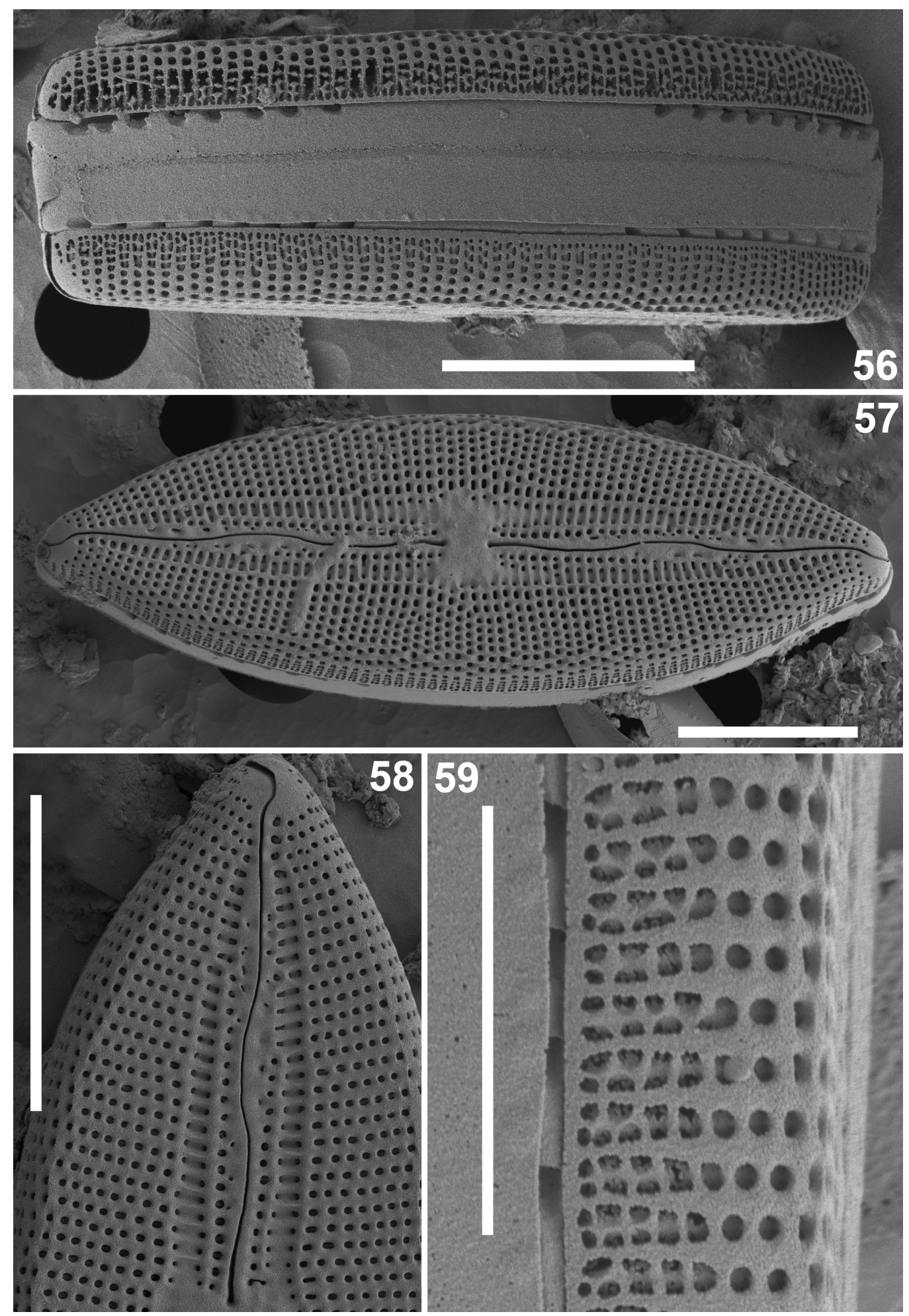

Figs 56-59. Mastogloia senegalensis Van de Vijver, Fofana, Sow \& Ector sp. nov. Scanning electron micrographs (SEM) of valves from the Lac de Guiers type population (Van de Vijver sample SEN-42). 56. SEM girdle view of an entire frustule showing the partectal pores and the mantle areolae. 57. SEM external view of an entire valve with typical undulating raphe branches. 58. SEM external detail of the apex and the axial area with the depressed grooved on both sides of the raphe. 59. SEM external detail of the valve mantle. Scale bars: $10 \mu \mathrm{m}$. 

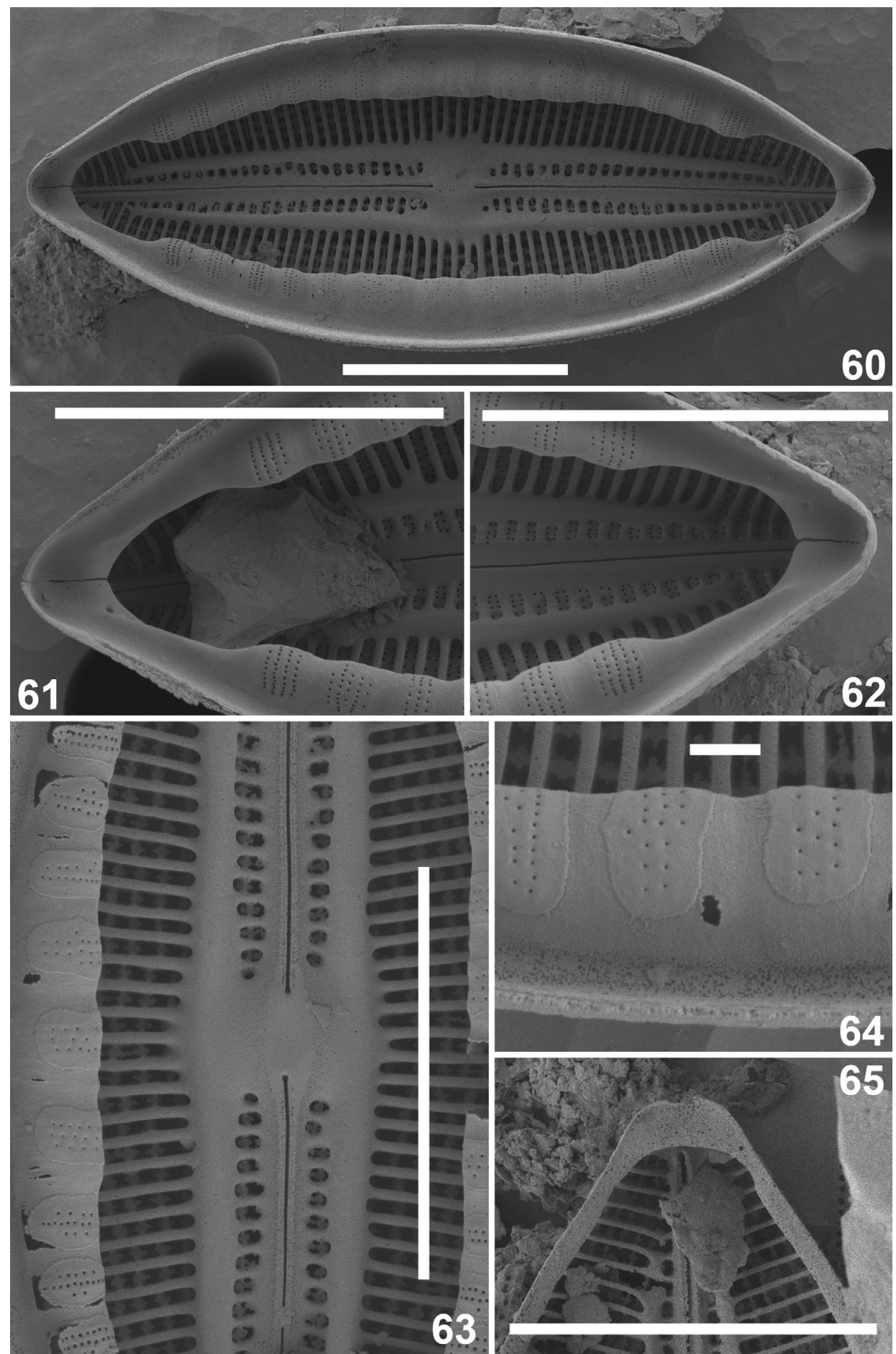

Figs 60-65. Mastogloia senegalensis Van de Vijver, Fofana, Sow \& Ector sp. nov. Scanning electron micrographs (SEM) of valves from the Lac de Guiers type population (Van de Vijver sample SEN-42). 60. SEM internal view of an entire valve with the partectal ring. 61-62. SEM internal details of the partectal ring near the valve apices showing the cleft on each apex. 63. SEM internal detail of the central area and part of the partectal ring. 64. SEM internal detail of the partecta showing the partectal walls with 2-4 series of small, rounded pores loosely aggregated in distinct plaques. 65. SEM internal view of a valve apex without the partectal ring (note the small pseudoseptum). Scale bars: $60-63,65=10 \mu \mathrm{m}$; $64=1 \mu \mathrm{m}$. 
mantle junction, biseriate near the mantle edge, composed of several rounded to irregularly shaped pseudoloculi (Fig. 59). Valve face clearly subdivided into two zones: outer zone composed of uniseriate striae, with up to 3-7 rounded pseudoloculi, central zone restricted to both sides of the raphe-sternum, formed by a shallow, but distinct lanceolate median depression (Fig. 57). Close to the raphe, one row of irregularly scattered rounded pseudoloculi present (Fig. 58), whereas in the depressions on both sides of the axial area, pseudoloculi transapically elongated, rectangular, diminishing in size towards the apices (Fig. 58). Central area slightly raised, thickened. Small hyaline areas present at the apices (Figs 57-58). Shallow irregular depressions sometimes visible in the axial area (Figs 57-58). Internally, hyaline raphe sternum H-shaped lyriform, clearly raised (Figs 60, 63). Well-developed, raised costa-like interstriae interrupted by the raphe-sternum extending from the axial area towards the valve margins, separating the areolae (Figs 60, 63). Inner areolae arranged in groups of 6 per pseudoloculus (Fig. 62). Raphe branches straight with indistinct, slightly deflected proximal endings, terminating on a weakly raised central nodule (Figs 60,63). Valve apices with small pseudosepta covering the distal raphe endings (Fig. 65).

Girdle composed of the valvocopulae and one open, non-perforated copula (Fig. 56). Valvocopulae with partectal ring, opening near the apices through a series of partectal pores (Figs 56, 59). Partectal ring opening at the poles by a cleft, covering entirely the pseudosepta (Figs 60-62). Lacunae never present (Figs 61-62). Partecta extending almost entirely to the valve apex, with only a small siliceous flange (Figs 60,64). Partecta subequal in size with the large ones grouped in the middle, the smaller ones nearer to the apices (Fig. 60). Partecta ornamented with several series of small, rounded areolae, loosely aggregated in distinct plaques and arranged inwardly (Fig. 64).

\section{Discussion}

Hustedt (1933) subdivided the genus Mastogloia into 11 different sections mainly based on the structure, number and organization of the partecta. One of these sections, ' $M$. sect. Sulcatae', presents valves with a typical median depression on both sides of the raphe sternum, often also visible internally as lateral sterna. Pennesi et al. $(2011,2012)$ revised 'M. sect. Sulcatae' and proposed two subgroups, a first one showing external siliceous outgrowths in the median depression, and a second one only showing the median depression. It is clear that both species observed in the Lac de Guiers material belong to the 'Sulcatae subgroup 2' as defined by Hustedt (1933) and Pennesi et al. (2012). The valves of M. belaensis showed a clear H-shaped sternum in LM although based on SEM observations the lateral hyaline zones are almost not depressed whereas the internal views clearly indicated the presence of a raised, lyreshaped lateral sternum. Therefore, the assignment of this taxon to the 'Sulcatae subgroup 2' is justified. Moreover, species belonging to this section have typical undulating external raphe branches, a feature clearly observed in M. belaensis.

Although morphologically closely related, the analysis of the Lac de Guiers material based on both LM and SEM observations, confirmed the presence of two separate taxa. Differences could be noted in the shape and structure of the partectal ring, the structure of the raphe, the structure of the mantle areolae and the structure of the valve face. Mastogloia belaensis showed a typical flange separating the partecta from the valve margins and the presence of a lacuna on one apex. Both features are absent in M. senegalensis sp. nov. Moreover, M. senegalensis sp. nov. showed a longer series of partecta, reaching closer to the valve apices than in $M$. belaensis, where the series of partecta terminated at about $1 / 4$ to $1 / 6$ of the valve apices. The raphe in M. belaensis showed more clearly undulating external raphe branches than in M. senegalensis sp. nov. Mastogloia senegalensis sp. nov. has a biseriate part in the mantle striae whereas in M. belaensis the mantle striae are uniseriate with transapically elongated, rectangular pseudoloculi. On the valve face in M. belaensis, a hyaline lyre-shaped non-depressed sternum could be observed whereas in $M$. senegalensis sp. nov., this structure presented a typical depression. Both taxa also differ in the structure of their pseudoloculi. Internally, M. belaensis shows an irregular number of 
areolae whereas in M. senegalensis sp. nov., a rather constant number of six areolae per pseudoloculus has been observed.

The first Mastogloia taxon from the Lac de Guiers could be identified as M. belaensis, originally described by Voigt from Pakistan in 1956 where it was found in some hot springs in the lower Hab River near Karachi (Voigt 1956). Unfortunately, the species was only illustrated by one picture. A morphological comparison with the illustration and the description in Voigt (1956) suggests an identification of valves from Lac de Guiers population as M. belaensis. The type material of M. belaensis has unfortunately never been investigated in detail using SEM techniques (Gaul et al. 1993; Henderson \& Reimer 2003) as despite some efforts, it could not be retrieved. Although only one single LM picture was shown in Voigt (1956), there seem to be hardly any morphological differences between the valve from Pakistan and those of the Lac de Guiers population. The valve dimensions match entirely the numbers mentioned in the original description although the largest valves from the Lac de Guiers population are slightly larger $(99 \mu \mathrm{m}$ vs $92 \mu \mathrm{m})$ with a higher number of pseudoloculi in $10 \mu \mathrm{m}$. The smaller valves that were observed could be identified as M. belaensis var. elliptica M.Voigt, described from the same habitats as the nominate variety (Voigt 1956). However, SEM observations of a large range of valves showed no structural differences. In the original description, Voigt (1956) indicated $9 \mu \mathrm{m}$ as minimum valve width, a number never reached in the valves from Lac de Guiers population. Other Mastogloia taxa belonging to ' $M$. sect. Sulcatae' all showed sufficient differences to be separated from M. belaensis, differing mostly in having a more developed lyre-shaped sternum (e.g., M. braunii, M. vasta Hust., M. lyra Lobban \& Pennesi and M. vestigiostriata Al-Handal \& Pennesi) or a different partecta-arrangement (e.g., M. sergeiana Pennesi \& Poulin, M. exilis Hust. and M. pumila var. papuarum Cholnoky) (Hustedt 1933; Cholnoky 1963; Pennesi et al. 2012; Lobban \& Pennesi 2014; Al-Handal et al. 2015). Two recently described Mastogloia taxa (M. abnormis Al-Handal \& Pennesi and M. descrepata Pennesi \& Al-Handal) show a close resemblance to $M$. belaensis (Al-Handal et al. 2016). Both taxa could be separated in being smaller with less undulating raphe branches and the absence of lacunae in the partectal ring. Moreover, the middle partecta in M. belaensis are larger than the other partecta whereas in M. descrepata, all partecta are uniform in size and shape.

Mastogloia belaensis is poorly known worldwide. Apart from the original description from Pakistan (Voigt 1956), only a few records exist. Munir et al. (2013) showed one LM picture of M. belaensis from Lake Kallar Kahar, an inland brackish water body situated in District Chakwal, Pakistan. Furthermore, only one other literature record of $M$. belaensis could be confirmed whereas another could be added after correction of the original identification. Witkowski et al. (2000: pl. 74 fig. 1) showed one picture from the Moroccan coast. The other population that is identified in Witkowski et al. (2000: pl. 84 figs 14-17) as $M$. belaensis shows a complete different partecta structure and should therefore not be identified as M. belaensis. A second observation was made by Gasse (1986: pl. 12 figs 4-5) from Lake Gamari (Ethiopia) who misidentified it as the more common species M. braunii but analysis of the published picture revealed that it should be identified as M. belaensis.

The second species, $M$. senegalensis sp. nov., shows some similarity with $M$. braunii, a species described by Grunow in 1863 from El Tor, Egypt. Until now, the type material of this Grunow taxon has never been analysed. All comparisons were based on other populations. Stephens \& Gibson (1980) illustrated four valves of a presumable population of M. braunii from Florida whereas Navarro (1988) showed SEM illustrations of several valves from a population of Cabo Rojo, a municipality situated on the southwest coast of Puerto Rico. The Lac de Guiers population differs however from both published records in having a different stria structure on the mantle. The population in Stephens \& Gibson (1980) presents uniseriate mantle striae with transapically elongated pseudoloculi whereas the Lac de Guiers population has typically biseriate striae on the mantle. Apart from the mantle striae, several other differences could be noted. The central area in the Lac de Guiers population is larger and more rectangular in comparison 
with the illustrated populations from Puerto Rico and Florida. Valves from both populations from Florida and Puerto Rico have a more slender, strictly lanceolate valve outline, whereas valves from the Lac de Guiers population has clearly elliptic-lanceolate valves.

Analysis of the type material of $M$. braunii, however, revealed that the population illustrated by Stephens \& Gibson (1980) does not represent M. braunii s. str. and most likely should be described as a new taxon. The main difference with M. braunii, as it was described by Grunow (1863), consists in the structure of the mantle striae. Mastogloia braunii s. str. has mantle striae that are uniseriate near the valve face/mantle junction, becoming biseriate near the mantle edge, composed of several rounded to irregularly shaped pseudoloculi whereas M. braunii sensu Stephens \& Gibson (1980) show only one elongated pseudoloculus following a small rounded one. The same applies for the Navarro (1988) population from Puerto Rico. Pennesi et al. (2011, 2012), Lobban \& Pennesi (2014) and Al-Handal et al. (2015), discussing species from 'M. sect. Sulcatae', all compared their species with M. braunii (as illustrated by Stephens \& Gibson 1980) but none of them discussed the shape of the mantle areolae, although it is clear that there is quite some variability in the structure and organization of the mantle areolae. Mastogloia lyra has a very shallow mantle on which the valve face striae continue as uniseriate rows of small pseudoloculi (Lobban \& Pennesi 2014). Mastogloia vestigiostriata has a well-developed mantle with uniseriate striae composed of large pseudoloculi (Al-Handal et al. 2015). Mastogloia pisculus Cleve shows similar biseriate striae on the mantle as in the Lac de Guiers population (Pennesi et al. 2012). Mastogloia sirbonensis A.Ehrlich, described from Egypt, is somewhat similar but has
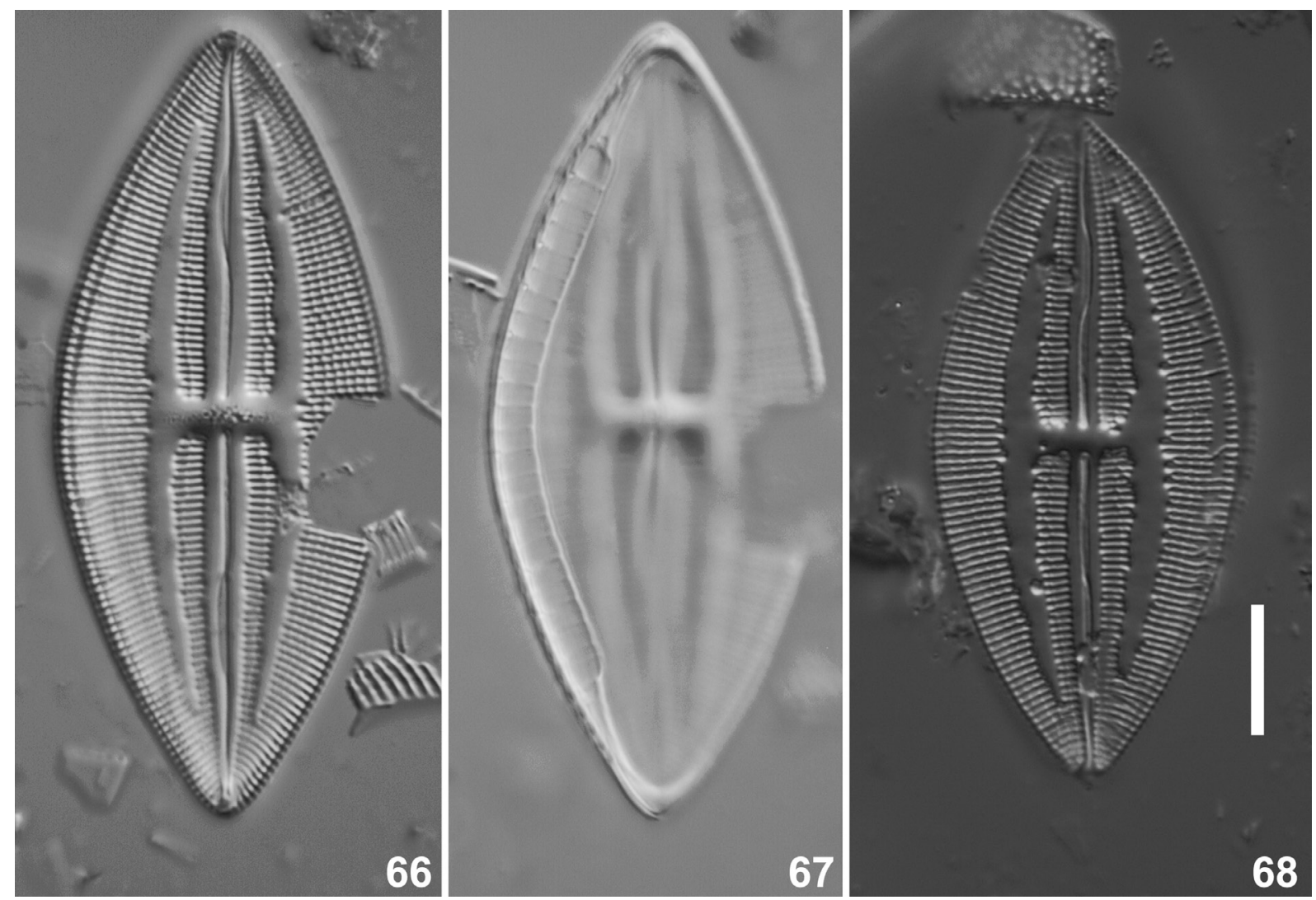

Figs 66-68. Mastogloia baldjikiana Grunow. Light micrographs (LM) of valves from slide 545 (Baldjick, Types du Synopsis des diatomées de Belgique, Van Heurck collection, BR). 66-67. Same valve taken at different foci. 66, 68. LM views of 2 valves showing variation in valve size and shape. 67. LM view of the partectal ring with the partecta. Scale bar: $10 \mu \mathrm{m}$. 
smaller valve dimensions (maximum width up to $14 \mu \mathrm{m}$ whereas $M$. senegalensis sp. nov. goes up to $17 \mu \mathrm{m})$ and two very large middle partecta, extending out of the partectal ring, a feature never observed in M. senegalensis sp. nov., where the middle partecta are larger but never extending (Ehrlich 1975). The three discussed Mastogloia taxa show some resemblance with M. baldjikiana. Analysis of slide 545 from the Types du Synopsis des diatomées de Belgique, made from a sample taken at Baldjick (Baltschik), Bulgaria (Figs 66-68), revealed a large Mastogloia species with a lyrate hyaline structure as could be observed in the three Mastogloia species discussed in this paper. However, this structure is much larger and more heavily silicified in M. baldjikiana compared to the three taxa discussed in this paper. Moreover, the valves have a more elliptic-rhombic valve outline with a lower length/width ratio compared to $M$. braunii, $M$. senegalensis sp. nov. and M. belaensis. Additionally, M. baldjikiana possesses partecta having an equal width and length throughout the entire partectal ring, contrary to M. braunii, M. senegalensis sp. nov. and M. belaensis that have larger partecta in the middle compared to the ones at the end of the partectal ring. These differences exclude totally any conspecificity with all three discussed taxa.

Mastogloia senegalensis sp. nov. can be separated from M. braunii s. str. based on the structure of the valvocopula. The analysis of the $M$. braunii type material clearly showed the presence of two lacunae whereas the Senegal population never showed lacunae. These lacunae are one of the discriminating features according to Paddock \& Kemp (1990). Based on valve dimensions, M. braunii is always a lot larger with a valve width often exceeding $20 \mu \mathrm{m}$ whereas the Senegal population, despite being very large never showed valves wider than $17 \mu \mathrm{m}$ with a higher stria density (16-18 vs 15-16 in $10 \mu \mathrm{m})$. The valve outline slightly differs. Mastogloia braunii s. str. shows more apiculate valves with acutely rounded, protracted apices whereas in the Senegal population, the apices are more truncated, less protracted, though still acutely rounded. Based on these differences and the absence of other comparable taxa, the description of the Senegal populations as a new species is justified.

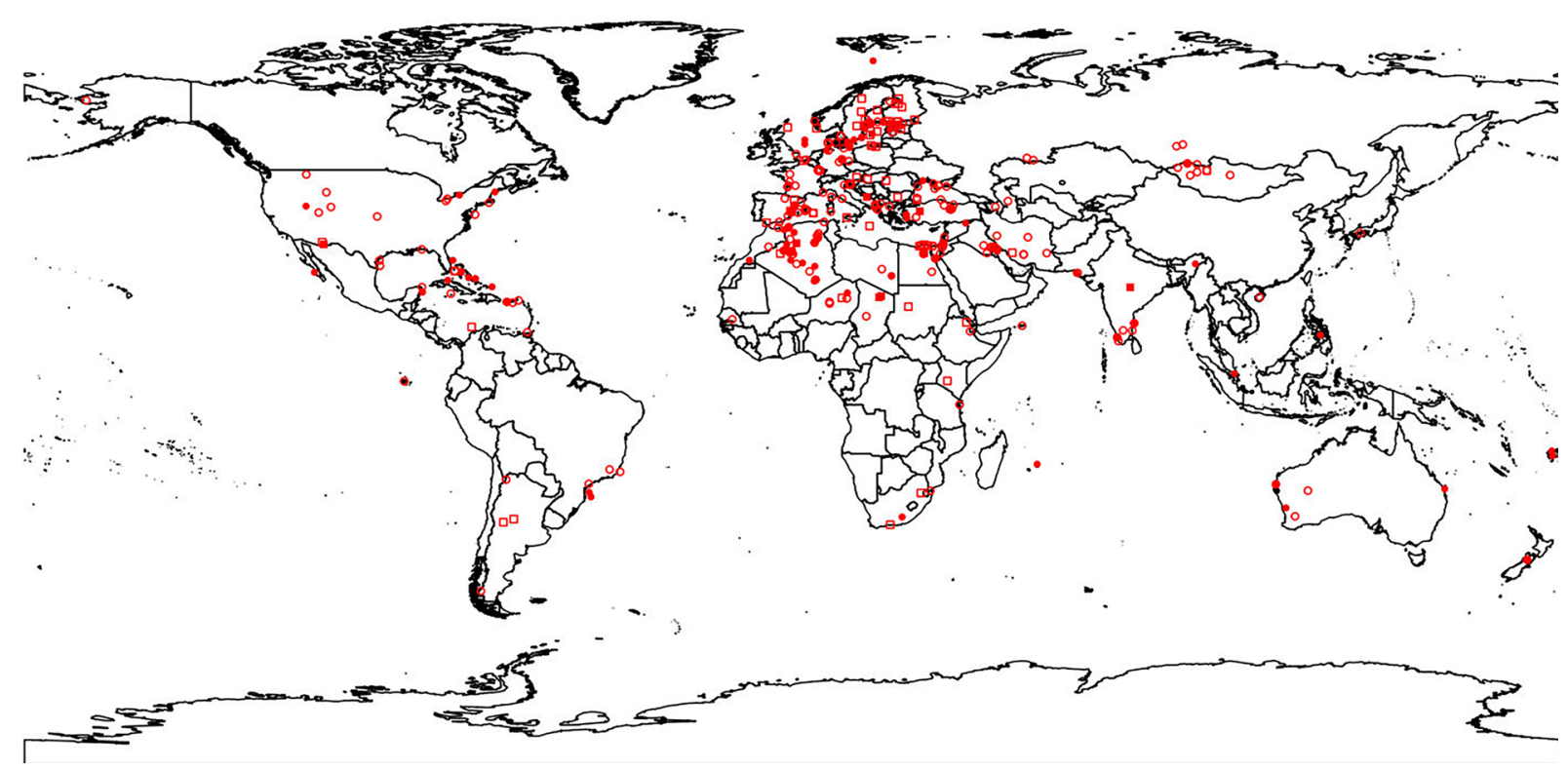

Fig. 69. World distribution of Mastogloia braunii s. lat. according to the literature. Circles: recent records. Squares: fossil records. Filled symbols indicate confirmed (illustrated) records. 331 locations were found based on 271 references. 
Mastogloia braunii s. lat. has been reported from a large number of localities worldwide (Fig. 69). Fig. 69 shows the geographical distribution of this species based on the literature. It is clear that most records originate from the northern hemisphere, more specifically from Europe, northern Africa and the Middle East. It is, however, unclear whether all these records represent $M$. braunii s. str. or belong in fact to other, probably undescribed taxa. In Africa, the species was only rarely observed, and also these records need to be verified.

\section{Acknowledgements}

The project was financed by the Agence universitaire de la Francophonie (AUF) (project n ${ }^{\circ}$ D-2092 RR 723). We would like to thank Dr. Anton Igersheim (Grunow Collection, Natural History Museum Vienna, Austria), for sending us the type material of Mastogloia braunii. Dr. Christopher S. Lobban and Dr. Chiara Pennesi are thanked for stimulating discussions. The new JEOL-JSM-7100F SEM facilities at the Botanic Garden Meise has been realized with the financial support of the IWT. Two anonymous reviewers are thanked for their comments that helped to improve this manuscript.

\section{References}

Alfinito S. \& Lange-Bertalot H. 2003. Contribution to the knowledge of the freshwater algae of Sierra Leone (Tropical West Africa): diatoms from Loma Mountains and Bumbuna Falls, the Northern Province. Biodiversity Journal 4 (1): 135-178.

Al-Handal A.Y., Pennesi C. \& Abdullah D.S. 2015. Two new species of Mastogloia Thwaites ex W. Smith (Bacillariophyceae) from Sawa Lake, southern Iraq. Fottea 15 (2): 155-164. https://doi.org/10.5507/fot.2015.016

Al-Handal A.Y., Pennesi C. \& Abdullah D.S. 2016. Mastogloia abnormis sp. nov. and Mastogloia descrepata sp. nov. (Bacillariophyceae, Mastogloia section Sulcatae) from Sawa lake, Southern Iraq. Diatom Research 31 (2): 113-121. https://doi.org/10.1080/0269249X.2016.1188859

Carter J.R. \& Denny P. 1982. Freshwater algae of Sierra Leone III. Bacillariophyceae: Part (i) Diatoms from the River Jong (Taia) at Njala. Beihefte zur Nova Hedwigia 73: 281-331.

Carter J.R. \& Denny P. 1987. Freshwater algae of Sierra Leone IV. Bacillariophyceae: Part (ii) diatoms from the coastal region of the southern province. Nova Hedwigia 44 (1-2): 229-275.

Carter J.R. \& Denny P. 1992. Freshwater algae of Sierra Leone IV. Bacillariophyceae: Part (iii) diatoms from the Lake Sonfon region and from Lake Popei. Nova Hedwigia 54 (1-2): 159-211.

Cholnoky B.J. 1963. Ein Beitrag zur Kenntnis der Diatomeenflora von Holländisch-Neuguinea. Nova Hedwigia 5 (1-2): 157-198, pls 25-27.

Compère P. 1991. Contribution à l'étude des algues du Sénégal 1. Algues du lac de Guiers et du BasSénégal. Bulletin du Jardin Botanique National de Belgique / Bulletin van de Nationale Plantentuin van België 61 (3/4): 171-267. https://doi.org/10.2307/3668149

Compère P. \& Riaux-Gobin C. 2009. Diatomées de quelques biotopes marins, saumâtres et dulçaquicoles de Guinée (Afrique occidentale). Systematics and Geography of Plants 79 (1): 33-66.

Dia A. \& Reynaud P.A. 1982. Le phytoplancton du lac de Guiers: approche qualitative et quantitative. Cahiers O.R.S.T.O.M., Série Biologie 45: 35-47.

Ehrlich A. 1975. The diatoms from the surface sediments of the Bardawil Lagoon (Northern Sinai) paleoecological significance. Beiheft zur Nova Hedwigia 53: 253-277, pls 1-3.

Foged N. 1966. Freshwater diatoms from Ghana. Biologiske Skrifter Det Kongelige Danske Videnskabernes Selskab 15 (1): 1-169, pls 1-25. 
VAN DE VIJVER B. et al., Mastogloia in Lac de Guiers, Senegal

Foged N. 1986. Diatoms in Gambia. Bibliotheca Diatomologica 12: 1-153.

Gasse F. 1986. East African diatoms. Taxonomy, ecological distribution. Bibliotheca Diatomologica 11: 1-203, pls 1-44.

Gaul U., Geissler U., Henderson M., Mahoney R. \& Reimer C.W. 1993. Bibliography on the finestructure of diatom frustules (Bacillariophyceae). Proceedings of the Academy of Natural Sciences of Philadelphia 144: 69-238.

Graeff C.L., Kociolek J.P. \& Rushforth S.R. 2013. New and interesting diatoms (Bacillariophyta) from Blue Lake Warm Springs, Tooele County, Utah. Phytotaxa 153 (1): 1-38. https://doi.org/10.11646/phytotaxa.153.1.1

Grunow A. 1863. Ueber einige neue und ungenügend bekannte Arten und Gattungen von Diatomaceen. Verhandlungen der Kaiserlich-Königlichen Zoologisch-Botanischen Gesellschaft in Wien 13: 137-162, pls. 13-14.

Guermeur P. 1954. Diatomées de l'A.O.F. (première liste : Sénégal). Institut Français d'Afrique Noire. Catalogues 12: 1-137, IFAN, Dakar.

Henderson M.V. \& Reimer C.W. 2003. Bibliography on the fine structure of diatom frustules (Bacillariophyceae). II. (+ deletions, addenda and corrigenda for bibliography I). Diatom Monographs 3: $1-372$.

Hustedt F. 1933. Die Kieselalgen Deutschlands, Österreichs und der Schweiz unter Berücksichtigung der übrigen Länder Europas sowie der angrenzenden Meeresgebiete. In: Rabenhorst L. (ed.) Kryptogamen Flora von Deutschland, Österreich und der Schweiz. Vol. 7 (Teil 2, Lief. 3): 321-432, f. 781-880. Akademische Verlagsgesellschaft m.b.h., Leipzig.

Kemp K.-D. \& Paddock T.B.B. 1989. Chambers within the valve of Diadema, gen. nov. Diatom Research 4 (1): 39-45. https://doi.org/10.1080/0269249X.1989.9705050

Lee S.S., Gaiser E.E., Van de Vijver B., Edlund M.B. \& Spaulding S.A. 2014. Morphology and typification of Mastogloia smithii and M. lacustris, with descriptions of two new species from the Florida Everglades and the Caribbean region. Diatom Research 29 (4): 325-350. https://doi.org/10.1080/0269249X.2014.889038

Lobban C.S. \& Pennesi C. 2014. Two new Mastogloia species (Bacillariophyceae), M. parlibellioides and M. lyra, from coral reefs in Guam, Western Pacific. Botanica Marina 57 (1): 41-54. https://doi.org/10.1515/bot-2013-0020

Medlin L.K. \& Kaczmarska I. 2004. Evolution of the diatoms: V. Morphological and cytological support for the major clades and a taxonomic revision. Phycologia 43 (3): 245-270. https://doi.org/10.2216/i0031-8884-43-3-245.1

Mereschkowsky C. 1903. Tipy endokhroma u Diatomovykh. Predvaritel'nyj otchet o vnutrennom stroenii diatomovykh. Les types de l'endochrome. Scripta Botanica Horti Universitatis Imperialis Petropolitani (Botanisheskia Zapiski) 21: 1-193 [1-106 in Russian, 107-193 in French].

Munir M., Qureshi R., Laghari M.K., Arshad M. \& Khaliq Chaudhry A. 2013. Taxonomy of some pennate diatoms from Kallar Kahar Lake, District Chakwal, Pakistan. The Journal of Animal \& Plant Sciences 23 (2): 457-463.

Navarro J.N. 1988. Diatomeas en tapetes microbianos de Puerto Rico. Gayana Botanica 45 (1-4): 275281. 
Novarino G. 1989. An update of the taxa of the genus Mastogloia, with a 'resemblance list' for the more recently described ones. Diatom Research 4 (2): 319-343. https://doi.org/10.1080/0269249X.1989.9705079

Ouattara A., Podoor N., Teugels G.G. \& Gourène G. 2000. Les micro-algues de deux cours d'eau (Bia et Agnébi) de Côte d'Ivoire. Systematics and Geography of Plants 70: 315-372. https://doi.org/10.2307/3668650

Paddock T.B.B. \& Kemp K.-D. 1990. An illustrated survey of the morphological features of the diatom genus Mastogloia. Diatom Research 5 (1): 73-103. https://doi.org/10.1080/0269249X.1990.9705095

Pavlov A., Jovanovska E., Wetzel C.E., Ector L. \& Levkov Z. 2016. Freshwater Mastogloia (Bacillariophyceae) taxa from Macedonia, with a description of the epizoic M. sterijovskii sp. nov. Diatom Research 31 (2): 85-112. https://doi.org/10.1080/0269249X.2016.1157376

Pennesi C., Poulin M., De Stefano M., Romagnoli T. \& Totti C. 2011. New insights to the ultrastructure of some marine Mastogloia species section Sulcatae (Bacillariophyceae), including M. neoborneensis sp. nov. Phycologia 50 (5): 548-562. https://doi.org/10.2216/10-39.1

Pennesi C., Poulin M., De Stefano M., Romagnoli T. \& Totti C. 2012. Morphological studies of some marine Mastogloia (Bacillariophyceae) belonging to section Sulcatae, including the description of new species. Journal of Phycology 48 (5): 1248-1264. https://doi.org/10.1111/j.1529-8817.2012.01215.x

Pennesi C., Poulin M., Hinz F., Romagnoli T., De Stefano M. \& Totti C. 2013. Comparison of two new species of Mastogloia (Bacillariophyceae) with other small members of section Ellipticae. Phytotaxa 126 (1): 1-21. https://doi.org/10.11646/phytotaxa.126.1.1

Pinto J. 1948. Protozoários, diatomáceas e outros organismos do plankton da Guiné Portuguesa. Junta das missões geograficas e de investigações coloniais 3 (4): 19-54.

Round F.E., Crawford R.M. \& Mann D.G. 1990. The diatoms: Biology and Morphology of the genera. Cambridge University Press, Cambridge.

Schmidt A. 1893. Atlas der Diatomaceen-kunde. Series IV (Heft 47): pls 185-188. O.R. Reisland, Leipzig.

Smith W. 1856. A synopsis of the British Diatomaceae; with remarks on their structure, functions and distribution; and instructions for collecting and preserving specimens. Vol. 2: pls 32-62, A-E. John Van Voorst, London. https://doi.org/10.5962/bhl.title.10706

Stephens F.C. \& Gibson R.A. 1980. Ultrastructural studies of some Mastogloia (Bacillariophyceae) species belonging to the group Sulcatae. Nova Hedwigia 33: 219-248.

Van der Werff A. 1955. A new method of concentrating and cleaning diatoms and other organisms. Verhandlungen der Internationalen Vereinigung für Theoretische und Angewandte Limnologie 12: 276277.

Voigt M. 1956. Some Mastogloia from Pakistan. Journal of the Royal Microscopical Society ser. 3 75 (3): 189-193. https://doi.org/10.1111/j.1365-2818.1955.tb00425.x

Witkowski A., Lange-Bertaltot H. \& Metzeltin D. 2000. Diatom flora of marine coasts I. Iconographia Diatomologica 7: 1-925.

Woodhead W. \& Tweed R.D. 1958. Freshwater Algae of Sierra Leone. I. New and unusual algae from the Sula Hills. Hydrobiologia 12 (2/3): 181-225. https://doi.org/10.1007/BF00034148

Zanon V. 1941. Diatomee dell'Africa Occidentale Francese. Commentationes Pontificia Academia Scientiarum 5 (1): 1-60. 
Manuscript received: 11 May 2017

Manuscript accepted: 11 July 2017

Published on: 5 December 2017

Topic editor: Frederik Leliaert Ph.D., Koen Martens

Desk editor: Alejandro Quintanar

Printed versions of all papers are also deposited in the libraries of the institutes that are members of the EJT consortium: Muséum national d'Histoire naturelle, Paris, France; Botanic Garden Meise, Belgium; Royal Museum for Central Africa, Tervuren, Belgium; Natural History Museum, London, United Kingdom; Royal Belgian Institute of Natural Sciences, Brussels, Belgium; Natural History Museum of Denmark, Copenhagen, Denmark; Naturalis Biodiversity Center, Leiden, the Netherlands; Museo Nacional de Ciencias Naturales-CSIC, Madrid, Spain; Real Jardín Botánico de Madrid CSIC, Madrid, Spain. 